Journal of Extension Education

Vol. 28 No. 4, 2016

DOI:https://doi.org/10.26725/JEE.2016.4.28.5747-5752

\title{
Marketing Behaviour of Jasmine Growers
}

\section{P. Bagya Janani ${ }^{1,}$ R. Premavathi ${ }^{2,}$ and R. Sasikala ${ }^{3}$}

\begin{abstract}
The present study was conducted in select villages of Tirunelveli district of Tamil Nadu in order to know the marketing behaviour of jasmine growers with a sample size of 120 respondents. The respondents were selected based on proportionate random sampling method. The results of the study revealed that majority of the jasmine growers were using polythene bags for packing the produce and sold their produce through commission agents. More than two - fifths sold their produce in the villages. Majority of the respondents considered 'immediate payment' as the main criterion for the selection of market. Majority of the respondents had reported that they were not having sufficient marketing facility.
\end{abstract}

\section{INTRODUCTION}

Tamil Nadu is the leading producer of jasmine in the country with an annual production of 92951 tonnes and productivity of 8.75 tonnes per hectare from the cultivated area of 10623 ha (Bagya janani et al, 2016). The flowers produced in the state are being exported to the neighbouring countries viz., Sri Lanka, Singapore, Malaysia and Middle East countries. The major jasmine producing districts of Tamil Nadu are Dindigul, Salem, Madurai, Tirunelveli, Virudhunagar and Trichy. Since the crop requires lots of manpower for harvesting and other operations, only small farmers are cultivating the crop. Tirunelveli districts ranks first in area under jasmine cultivation with the area of 1267.25 ha (Bagya janani et al, 2016).

Marketing of jasmine is more complicated as majority of the farmers are illiterate, unorganized and scattered. They do not have the required knowledge and skill for marketing of their produce. They are forced to sell their produce immediately after the harvest at low prices in the village itself to the local traders. Taking into account these factors, the present study was take up.

\section{METHODOLOGY}

Tirunelveli district in Tamil Nadu was purposively selected, as area under jasmine cultivation in high. Tirunelveli district consists of nineteen blocks, out of which Vallioor block was selected, as

\footnotetext{
1. Rural Development Officer, Union Bank of India, Madurai 2. Associate Professor (Agrl.Extension),Department of Agricultural Extension and Rural Sociology, TNAU, Coimbatore and 3. Assistant Professor (Journalism), Directorate of Extension Education, TNAU, Coimbatore.
} 
this block had more area under jasmine cultivation. In Vallioor block, jasmine was cultivated in an area of 390.46 ha during 2011-12. A sample of 120 jasmine growers was selected from three revenue villages based on proportionate random sampling method. Data were collected with the help of a well structured pretested interview schedule and analysed with suitable statistical techniques.

\section{FINDINGS AND DISCUSSION}

The marketing behaviour of jasmine growers was studied with eleven components namely, mode of packing, mode of transport, place of sales, nature of sales, weighing behaviour, selling in open market, distance of market, payment pattern, reason for selection of market, middle man involvement and opinion about existing market facilities.

The findings reveal that three-fifths of jasmine growers $(65.00 \%)$ had medium level of marketing behaviour where as one-fifth of the respondents (19.17\%) had low level of marketing behaviour. This was followed by 15.83 per cent of respondents with high level of marketing behaviour.

It could be understood that most of the respondents possessed low to medium level of marketing behaviour. This might be due to varied reasons such as, poor access to market and poor knowledge on recent market trends.

Table 1.

Distribution of Respondents According to Their Marketing Behaviour

$(\mathrm{n}=120)$

\begin{tabular}{|c|c|c|c|}
\hline S1.No. & Marketing behaviour & Number & Percentage \\
\hline 1. & $\begin{array}{l}\text { Mode of packing } \\
\text { Gunny bags } \\
\text { Polythene bags }\end{array}$ & $\begin{array}{l}48 \\
72\end{array}$ & $\begin{array}{l}40.00 \\
60.00\end{array}$ \\
\hline \multirow[t]{2}{*}{2.} & \multicolumn{3}{|l|}{ Mode of transport } \\
\hline & \begin{tabular}{|l} 
Head load \\
Bicycle \\
Bullock cart \\
Moped \\
City bus \\
Tractor \\
Tempo van
\end{tabular} & $\begin{array}{c}- \\
13 \\
- \\
60 \\
- \\
- \\
30\end{array}$ & $\begin{array}{c}- \\
10.83 \\
- \\
50.00 \\
- \\
- \\
39.17\end{array}$ \\
\hline \multirow[t]{2}{*}{3.} & \multicolumn{3}{|l|}{ Place of sale } \\
\hline & $\begin{array}{l}\text { Village itself } \\
\text { Nearby town } \\
\text { Faraway places }\end{array}$ & $\begin{array}{l}52 \\
39 \\
29\end{array}$ & $\begin{array}{l}43.33 \\
32.50 \\
24.17\end{array}$ \\
\hline
\end{tabular}




\begin{tabular}{|c|c|c|c|}
\hline \multirow[t]{6}{*}{4.} & Nature of sale & & \\
\hline & Local merchants & 12 & 10.00 \\
\hline & Retailers & - & - \\
\hline & Commission agents & 78 & 65.00 \\
\hline & Contractors & 18 & 15.00 \\
\hline & Wholesalers & 12 & 10.00 \\
\hline \multirow[t]{3}{*}{5.} & Weighing behaviour & & \\
\hline & Checking the weights & 120 & 100.00 \\
\hline & Not checking the weights & - & - \\
\hline \multirow[t]{3}{*}{6.} & Open market sale & & \\
\hline & Selling at open markets & 4 & 3.33 \\
\hline & Not selling at open markets & 116 & 96.67 \\
\hline \multirow[t]{3}{*}{7.} & Payment pattern & & \\
\hline & Fully & 52 & 57.78 \\
\hline & Partially & 38 & 42.22 \\
\hline \multirow[t]{4}{*}{8.} & Distance of market & & \\
\hline & $\mathrm{Up}$ to $10 \mathrm{~km}$ & - & - \\
\hline & $11-20 \mathrm{~km}$ & 97 & 80.83 \\
\hline & $21-30 \mathrm{~km}$ & 23 & 19.17 \\
\hline \multirow[t]{5}{*}{9.} & Reasons for selection of market & & \\
\hline & Nearness to the place of production & 18 & 15.00 \\
\hline & Receipt of advance & 24 & 20.00 \\
\hline & Higher prices & - & - \\
\hline & Immediate payment & 88 & 65.00 \\
\hline \multirow[t]{4}{*}{10.} & Middlemen involvement & & \\
\hline & No involvement & - & - \\
\hline & Partially & 43 & 35.83 \\
\hline & Fully & 77 & 64.17 \\
\hline \multirow[t]{4}{*}{11.} & Opinion about existing market facilities & & \\
\hline & Somewhat sufficient & - & - \\
\hline & Sufficient & 42 & 35.00 \\
\hline & Insufficient & 78 & 65.00 \\
\hline
\end{tabular}

\section{Mode of Packing}

Majority of the respondents $(60.00$ $\%)$ were found using polythene bags for packing the produce. Gunny bags were used by the remaining 40.00 percentage of the respondents.

It was observed during the survey that polythene bags were the easily available packing material to the villagers 
and they felt that the polythene bags would prevent aeration inside, which will prevent the buds from blooming. Hence, majority of the farmers used polythene bags as packing material. Big farmers use gunny bags as packing material because polythene bags will not be sufficient to pack their produce.

\section{Mode of Transport}

Hundred per cent of the jasmine growers reported that they transported their produce to markets. With regard to mode of transport, 50.00 per cent of the jasmine growers had used moped for transporting their produce. There were 39.17 per cent of the respondents who used tempo van for transporting the produce. It was observed during the survey that the farmers themselves form groups and make arrangements for transporting their produce. They also used bicycles $(10.83 \%)$ for transporting the produce.

It was observed during the survey that considerable proportion of the respondents had owned mopeds and therefore they utilized the moped to transport their produce. Bicycles were used for transporting the produce within the village.

\section{Place of Sale}

Majority of the jasmine growers $(43.33 \%)$ sold their produce in the village itself with the help of moped and bicycle. Following this 32.50 per cent of the jasmine growers had sold their produce in nearby towns and only 24.17 per cent of the jasmine growers sold their produce in faraway places with the help of tempo vans.

As most of them possessed tractors they would have preferred to sell at the markets located within $10 \mathrm{~km}$ distance. Those who possessed bicycles would have preferred the local sale in the village itself. Those who had more area of cultivation and harvested huge quantity would have preferred the city bus for transport.

\section{Sales Agency}

From Table 1, it is inferred that majority of the respondents $(65.00 \%)$ sold their produce through commission agents, followed by contractors $(15.00$ $\%)$.

Majority of the respondents expected immediate payment for their produce. The commission agents and local merchants also supply gunny bags and provide financial assistance during the time of cultivation of jasmine. Further, they are also easily approachable and familiar to the respondents. The above reasons would have motivated them to sell their produce through commission agents.

\section{Weighing Behaviour}

From the table, it could also be seen that 100 per cent of the jasmine growers were found to be checking the weights. 
Since the commission agents and contractors had friendly relationship with farmers and also the familiarity among the jasmine growers would have made the respondents to readily accept the weights.

\section{Open Market Sale}

It could be inferred from the table that majority ( $96.67 \%$ ) of the jasmine growers did not sell their produce in open market. Only 3.33 per cent of the jasmine growers sold their produce in open market due to immediate payment. The reason might be because village merchants, commission agents and the wholesalers to whom the produce was sold by the farmers showed positive attitude in getting back the money in right time and hence they did not go to open market to sell their produce.

\section{Payment Pattern}

Majority of the respondents $(80.00$ $\%)$ received full payment and the rest $(20.00 \%)$ received only partial payment.

The wholesaler, commission agents and village merchant who procure the entire produce from the farmers pay them the entire amount during procurement. The farmer who sells their produce to the contractor is paid partially because the farmer had got money from the contractor in advance.

\section{Distance of the Market}

It is seen that 80.83 per cent of the respondents sold their produce in the markets located within the distance of 10 $\mathrm{km}$.
It has already been discussed under 'place of sale' that most of the respondents sold their produce in the village itself. Wholesale market is located at the distance of about $30 \mathrm{~km}$ from the study area. It is too far and expensive for small and marginal farmers to take the risk of marketing the produce at wholesale market.

\section{Reasons for Selection of Market}

More than two-fifths $(45.00$ $\%)$ of the respondents considered the 'immediate payment' as the main criteria for the selection of market followed by receipt in advance (35.00\%).

The commission agents in nearby towns give immediate payment to the farmers. Hence, majority of the respondents expressed 'immediate payment' as reason for selection of the market.

\section{Middlemen Involvement}

Hundred per cent of the respondents had sold their produce through middlemen. No one had sold their produce directly.

Absence of institutional markets and prevailing dominance of private markets would have allowed the middlemen to flourish in marketing the produce of the farmers.

\section{Opinion about Existing Market Facilities}

Majority of the respondents $(65.00$

\%) reported that existing marketing 
facilities were not sufficient and the rest $(35.00 \%)$ were satisfied with the existing market facilities. Middlemen involvement and wholesale markets located at distance places were the major reasons for non satisfaction of the respondents.

\section{CONCLUSION}

The present study revealed that threefifths of jasmine growers had medium level of marketing behaviour followed by low level of marketing behaviour. As mass media usage was found high among the respondents, latest technologies and marketing information may be disseminated through these media for effective utilization of marketing facilities. To reduce high production costs, market committees can therefore help the farmers to get pledge loans to meet out the cultivation expenses by relaxing and simplifying the existing procedures and that could recovered at the time of sale of the produce. Further, as market potential plays a major role for high marketing behavior, field level marketing professionals under the control of Directorate of Agricultural Marketing should help in creating awareness among jasmine growers.

\section{REFERENCES}

Bagyajanani, P., Premavathi, R., \& Puthira Prathap, D. (2016). Technology Adoption behaviour of Jasmine Grosers- A Critical Analysis. Journal of Extension Education, 28(1)

Ganeshamoorthy, R. (2005). A Study on Adoption and Marketing Behavior of Turmeric Growers in Erode District of Tamilnadu. Unpublished M.Sc. (Ag.) Thesis, Agricultural College and Research Institute. TNAU, Madurai

Heddybai, L. (1994). Marketing Behaviour of Gardenland Farmers. Unpublished M.Sc.(Ag.) Thesis, Agricultural College and Research Institute, TNAU, Madurai.

Jaisridhar, P. (2009). Adoption and Marketing Behaviour of Maize Growers. Unpublished M.Sc.(Ag.) Thesis, Agricultural College and Research Institute, TNAU, Coimbatore.

Sathyachitradevi, M. (2006). Spread and Acceptance of Low Cost Technologies of Major Crops by Resources Poor Farmers. Unpublished M.Sc.(Ag.) Thesis, Agricultural College and Research Institute. TNAU, Coimbatore. 